\title{
REFLEXÕES SOBRE O DISFORME E O GROTESCO EM "BÁRBARA", CONTO DE MURILO RUBIÃO
}

\author{
REFLECTIONS ON THE DYSFORM AND GROTESQUE IN \\ "BÁRBARA", A SHORT STORY BY MURILO RUBIÃO
}

\author{
Antonia Marly Moura SILVA* \\ Vilmária Chaves NOGUEIRA**
}

\begin{abstract}
Resumo: O presente artigo tem como propósito realizar uma leitura do conto "Bárbara", do escritor mineiro Murilo Rubião, destacando o motivo do grotesco expresso na imagem monstruosa do corpo da personagem central, bem como o riso como traço ligado ao grotesco e ao sentimento de angústia. Nesse sentido, embasamo-nos em pensamentos de Bakhtin (1987), Hugo (2010), Kayser (2013), Connelly (2015) e Thomson (2019), principalmente em conceitos imbricados na abordagem analítica do conto. $\mathrm{Na}$ leitura pretendida, buscamos mostrar como a ficção muriliana se apropria de metáforas que potencializam o grotesco, especialmente no que se refere à representação do feminino. Desse modo, nosso interesse maior volta-se para aspectos ligados à construção da imagem da protagonista. Sob tal perspectiva, buscamos analisar as metáforas ligadas à construção do corpo da personagem e seus sentidos simbólicos dentro do constructo do enredo, mostrando, sobretudo, como tais elementos culminam para a configuração do riso grotesco. Por fim, podemos dizer que "Bárbara" é um conto que nos permite refletir sobre problemáticas significativas do contexto atual, como a imagem do corpo grotesco na literatura, o riso de horror, o disforme e a ironia sobre o padrão social de corpo imposto à mulher, assim como sua posição nas esferas particular e pública.
\end{abstract}

Palavras-chave: "Bárbara”. Conto. Grotesco. Corpo. Riso.

\begin{abstract}
This paper presents a reading of the short story "Bárbara", by Murilo Rubião, highlighting the reasons for the grotesque which is expressed in the monstrous image of the central character's body, as well as on laughter as a trait connected to grotesque and to anguish. It is anchored on thoughts of Bakhtin (1987), Hugo (2010), Kayser (2013), Connelly (2015) and Thomson (2019), mainly on concepts intertwined in the analytical approach of the short story. The reading shows how this piece of fiction appropriates metaphors that enhance the grotesque, especially regarding the representation of the feminine. The greatest interest centers in aspects related to the construction of the protagonist's image. From this perspective, an analysis of the metaphors linked to the construction of the character's body and its symbolic meanings within the plot construct is carried out, showing, above all, how such elements culminate in the configuration of grotesque laughter. Based on this analysis, it is possible to say that "Bárbara" is a short story that allows us to reflect on significant issues of the current context, such as the image of the grotesque body in literature, the laugh of horror, the misshapenness, and the irony about the social pattern of body imposed on women, as well as their position in the private and public spheres.
\end{abstract}

Keywords: "Bárbara". Short story. Grotesque. Body. Laughter.

\footnotetext{
* Doutora em Letras pela Universidade de São Paulo (USP); Docente do Departamento de Letras Vernáculas, vinculada ao Programa de Pós-Graduação em Letras/UERN. E-mail: marlymouras@uol.com.br. ORCID: https://orcid.org/0000-0002-2939-0626

** Doutoranda em Letras pelo Programa de Pós-Graduação em Letras (PPGL), da Universidade do Estado do Rio Grande do Norte (UERN). E-mail: vilmariachaves@ gmail.com. ORCID: https://orcid.org/0000-0002-9807-4846
} 


\title{
Algumas palavras sobre o grotesco
}

A origem da palavra grotesco é antiga e não nasceu como fenômeno literário. Inicialmente se referia às artes ornamentais, cuja existência é bem anterior ao surgimento do vocábulo e se referia a gravuras encontradas em grutas na Itália. Kayser (2013) recupera as raízes dessa palavra e, a princípio, situa o grotesco como um traço ligado à arte ornamental para, posteriormente, levantar suas dimensões literárias. Sobre a origem da palavra, assim sublinha Kayser:

\begin{abstract}
A "grotesco", isto é, grotesco, e os vocábulos correspondentes em outras línguas são empréstimos tomados do italiano. La grotesca e grotesco, como derivações de grota (gruta), forma palavras cunhadas para designar determinada espécie de ornamentação, encontrada em fins do século XV, no decurso de escavações feitas primeiro em Roma e depois em outras regiões da Itália. O que se descobriu foi uma espécie até então desconhecida de pintura ornamental antiga. (KAYSER, 2013, p. 17-18).
\end{abstract}

Referindo-se à obra de Friedrich Schlegel, Kayser (2013) identifica o grotesco como traço inerente à poesia. Em sua concepção

[p]or vagas que sejam as definições do conceito do grotesco na Conversão sobre a Poesia, elas contêm por certo, muitos dos elementos que nos pareceram essenciais: a mescla do heterogêneo, a confusão, o fantástico e é possível achar nelas algo como o estranhamento do mundo. Mas falta uma coisa: o caráter insondável, abismal, o interveniente horror em face das ordens em fragmentação (KAYSER, 2013, p. 55-56).

Questiona Kayser (2013, p. 56): “[o] que significa grotesco? [...] - é o contraste pronunciado entre forma e matéria (assunto), a mistura centrífuga do heterogêneo, a força explosiva do paradoxal, que são ridículos e horripilantes ao mesmo tempo".

Conforme indica o referido estudioso, o grotesco está também associado a uma arte alegre, mas ao mesmo tempo sinistra, cuja incidência, em suas formas primordiais, é bem acentuada em utensílios domésticos, como vasos de plantas e pratos, assim como em decorações de bibliotecas do século XVII e XVIII.

Cumpre ressaltar que o avanço teórico em torno do termo grotesco permite variadas perspectivas sobre suas características estéticas, dentre as quais consideramos fundamentais os postulados de Wolfgang Kayser, concebido como o mestre do grotesco romântico, bem como a concepção bakhtiniana ligada ao riso popular, que teve como pano de fundo o contexto da Idade Média e do Renascimento, sobretudo à obra de Rabelais. Oportunas, ainda, são as teorizações de Hugo (2010), Connelly (2015) e Thomson (2019) sobre a questão.

Sob a ótica de Kayser (2013), o grotesco opera no movimento com o burlesco, o bizarro, o cômico, o ridículo, o monstruoso, o disforme, dentre outras instâncias que acentuam sua 
ambivalência e permitem o jogo com a caricatura, com a estranheza e com a repulsa. Com efeito, da tradição à modernidade, o grotesco sempre teve um caráter subversivo, ligado ao disforme e ao estranho. Seus traços assimétricos, suas mesclas desproporcionais e sem lógica, assim como sua composição animalesca e monstruosa - uma das características principais dessa forma artística - foram motivos de acirradas críticas, o que contribuiu decisivamente para que não fosse dado o devido valor a esse estilo, pois a arte em questão se distanciava de tudo o que acentuava o belo e que suscitava boas sensações. Portanto, é uma categoria estética que desde sempre provocou a irrupção do conflituoso, através, sobretudo, da imagem, pois, conforme palavras de Connelly (2015, n.p., tradução nossa), “[...] o grotesco expressa sentido através do puramente visual. O grotesco é, na verdade, o jogo da imagem em ação, seu humor e irreverência oferecem um antídoto bem-vindo a qualquer forma de pensamento convencional ${ }^{1}$ ". Nota-se que a imagem é a chave para a construção do grotesco, mas não uma imagem qualquer, e sim um atributo que instaure um conflito, seja pelo exagero, seja pela deformidade.

Sobre o grotesco na literatura, pode-se dizer que quem primeiro pensou nessa relação foi o romancista francês Victor Hugo ao escrever o livro Do grotesco e do sublime (1827), um prefácio ao romance Oliver Cromwell. Para ele, as sociedades nem sempre foram habitadas pelos mesmos homens e os gêneros literários que surgiram ao longo da história retratam os indivíduos de cada época. Assim, Hugo (2010) destaca três grandes épocas. A primeira é a dos tempos primitivos. Nessa época, a terra era habitada por pequenos grupos familiares. Não havia guerras, como também não havia inquietação devido à ausência de disputas por territórios. Nesse período, reinou a poesia - um gênero que retratava essa paz de espírito e essa totalidade do homem. Com o tempo, as populações foram crescendo e povoando a terra. Começou a haver disputas de territórios. Nasceu o espírito do herói e com ele surgiu a epopeia que retratava as lutas de um povo. Mas é com o surgimento do cristianismo que a vida do homem passou a ser vista de forma diferente, pois esse movimento religioso instaurou a ideia da separação entre corpo e alma. Segundo Hugo (2010), é a partir desse momento que o ser humano passou a experimentar o sentimento da melancolia e da verdade. Conforme indicou o romancista:

O cristianismo conduz a poesia à verdade. Como ele, a musa moderna verá as coisas
com um olhar mais elevado e mais amplo. Sentirá que tudo na criação não é
humanamente belo, que o feio existe ao lado do belo, o disforme perto do gracioso, o
grotesco no reverso do sublime, o mal com o bem, a sombra com luz. Perguntar-se-á
se a razão estreita e relativa do artista deve ter ganho de causa sobre a razão infinita,
absoluta, do criador; se cabe ao homem retificar Deus; se uma natureza mutilada será

\footnotetext{
${ }^{1}$ No original: “[...] lo grotesco expresa significado a través de lo puramente visual. Lo grotesco es, en verdad, el juego de la imagen en acción, su humor e irreverencia ofrecen un antídoto de bienvenida a cualquier forma de pensamiento convencional"
} 
mais bela; se a arte possui o direito de desdobrar, por assim dizer, o homem, a vida, a criação; se cada coisa andará melhor, quando lhe for tirado o músculo e a mola; se, enfim, o meio de ser harmonioso é ser incompleto (HUGO, 2010, p. 26, negrito no original).

Para Hugo (2010), o drama é o gênero que mais se aproxima desse homem incompleto. É nele que primeiro aparece o grotesco. Sob sua ótica, o grotesco é indissociável da comédia, uma categoria estética sustentada por relações binárias como o feio e o belo, o bem e o mal, o disforme e o gracioso, dentre outras dualidades. Na visão do poeta, o grotesco surge não como algo fantasioso, mas como algo que revela a verdadeira face desse mundo moderno, pois a desordenação é uma característica das sociedades contemporâneas. Todavia, não se pode dizer que tudo que está desordenado possa ser visto como grotesco. Na verdade, nesse estilo artístico descoberto na Itália, existe uma preocupação com a aproximação em relação ao mundo real, uma vez que "[...] há uma humildade fundamental no grotesco, enraizada no corpo vivo (e morto), que tem a ver com o caráter relativo e mutável da vida como a vivemos ${ }^{2}$ " (CONNELLY, 2015, n.p., tradução nossa).

Outrossim, não podemos esquecer que, segundo Connelly (2015), o grotesco sempre busca ir além dos limites da realidade, das culturas, das crenças, etc, propondo perguntas e instaurando conflitos que parecem não se resolver. Além disso, essa arte “[...] nos leva mais além dos limites do mundo que conhecemos, também nos recorda nossos próprios limites e nossa própria mortalidade"3 (CONNELLY, 2015, n.p., tradução nossa).

Assim, o grotesco volta-se para lados obscuros do homem, direciona-se para aspectos da existência, mas não com ênfase nas análises introspectivas, e sim nos fatos e na angustiante sensação de desconforto que eles provocam, quando revelam a fragilidade e a pequenez do homem diante de tudo o que existe. Por isso, muitas vezes, o grotesco causa o riso.

No grotesco realista, esse riso procurava se aproximar ao máximo da cultura popular carnavalesca, sendo um riso, portanto, de renovação e de distanciamento da palavra e das crenças oficiais, aproximando-se também da linguagem popular. O riso, segundo postula Bakhtin (1987), que expressava, acima de tudo, a ideia de dualidade humana, mostrando o lado mais alegre e divertido do homem em comparação com o da Igreja; satirizava a vida e, portanto, nunca pôde ser oficial.

\footnotetext{
${ }^{2}$ No original: “[...] existe una humildad fundamental en lo grotesco, enraizada en el cuerpo vivo (y muerto), que tiene que ver con el carácter relativo y cambiante de la vida a medida que la vivimos."

${ }^{3}$ No original: "[...] nos lleva más allá de los límites del mundo que conocemos, también nos recuerda nuestros propios límites y nuestra propia mortalidad."
} 
No realismo grotesco, "[...] o princípio material e corporal aparece sob a forma universal, festiva e utópica. O cósmico social e o corporal estão ligados indissoluvelmente numa totalidade viva e indivisível. É um conjunto alegre e benfezado" (BAKHTIN, 1987, p. 17). O teórico russo ressalta que a versão moderna desse motivo artístico herdou características mais precisas da sua versão romântica, na qual o carácter alegre e descompromissado do riso sofre uma brusca alteração:

O princípio do riso sofre uma transformação muito importante. Certamente, o riso subsiste; não desaparece nem é excluído como nas obras "sérias"; mas no grotesco romântico o riso se atenua, e toma a forma de humor, ironia ou sarcasmo. Deixa de ser jocoso e alegre. $\mathrm{O}$ aspecto regenerador e positivo do riso reduz-se ao mínimo (BAKHTIN, 1987, p. 17).

Assim, percebe-se um tom de angústia e de horror no riso do grotesco moderno. Isso porque o objeto de riso apresenta aspectos, como já dissemos antes, em consonância com a realidade. Para Thomson (2019, n.p., tradução nossa), “o que geralmente se tem em acordo é que 'grotesco' abarca - talvez entre outras coisas - a presença ao mesmo tempo do risível e de algo que é incompatível com o risível ${ }^{4 \prime}$.

Bakhtin identifica a cosmovisão carnavalesca e o riso como características essenciais do grotesco. Segundo ele,

[o] riso e a visão carnavalesca do mundo, que estão na base do grotesco, destroem a seriedade unilateral e as pretensões de significação incondicional e intemporal e liberam a consciência, o pensamento e a imaginação humana, que ficam assim disponíveis para o desenvolvimento de novas possibilidades (BAKHTIN, 1987, p. 43).

No caráter burlesco do grotesco, seja na interpenetração com o riso, seja na comunhão com o estranho, tudo se conflui e se mistura promulgando um movimento com o assombro e com a monstruosidade. Thomson (2019) usa as palavras horror e desconforto para falar da sensação de estranheza do grotesco que causa o riso de angústia. Ele mostra que esse sentimento nasce do confronto entre incongruências. Na verdade, o grotesco coloca em evidência a tentativa de mesclagem entre realidades incompatíveis. Geralmente, quando se trata da literatura, essa incongruência pode vir através da ambientação, mas, nas narrativas fantásticas contemporâneas, é bem constante o destaque ao corpo das personagens como aspecto

\footnotetext{
${ }^{4}$ No original: "En lo que se estará por lo general de acuerdo es en que "grotesco" abarca - tal vez entre otras cosas - la presencia al mismo tiempo de lo risible y de algo que es incompatible con lo risible."
} 
privilegiado para a construção do grotesco e para a construção do assombro ou mesmo do medo, como assim querem alguns estudiosos. Sobre o corpo grotesco, Russo (2000) destaca que há uma maior predominância sobre o feminino. Para a estudiosa, a própria gruta (da qual se origina o nome grotesco) lembra o corpo da mulher com todas as suas curvas. Não obstante, em seu trabalho, diferentemente dos primeiros críticos da arte ornamental, a autora enaltece o grotesco e faz uma distinção no que se refere a sua manifestação no corpo:

O corpo clássico é transcendente e monumental, fechado, estático, contido em si mesmo, simétrico e liso; identifica-se com a cultura "superior" ou oficial do renascimento e de épocas posteriores, com o racionalismo, o individualismo e as aspirações normalizadores da burguesia. O corpo grotesco é aberto, protuberante, irregular, secretante, múltiplo e mutável; está identificado com a cultura "inferior" não-oficial ou com o carnavalesco, e com a transformação social (RUSSO, 2000, p. 21).

Frente a isso, entende-se que o grotesco se constitui por um desvio de normas. Porém, tal desvio não acontece por acaso. Os monstros grotescos certamente remetem a sensações e a lugares não tão comuns ao nosso cotidiano, porque tendemos a transmutar as imagens desagradáveis para o campo do inconsciente, uma vez que os mundos desordenados e assombrosos nos causam uma inquietação. Todavia, apesar de experimentarmos o sentimento repugnante diante das aberrações e dos monstros grotescos, ainda não conseguimos deixá-los distantes da nossa vida. Por isso, trazemos suas imagens nas artes ornamentais e na forma escrita literária.

Em suma, ligado à anomalia, o grotesco constitui-se como categoria do contraste, algo sinistro, tal como concebe Kayser (2013), ao referir-se ao sentido do termo à luz de Victor Hugo: “[...] pois grotesco é justamente contraste indissolúvel, sinistro, o que-não-devia-existir" (KAYSER, 2013, p. 61).

\section{A imagem grotesca do corpo em "Bárbara"}

O excesso e a metamorfose são duas vias que congregam para a construção do grotesco em algumas narrativas do escritor mineiro Murilo Rubião, tais como "O Homem do Boné Cinzento", "Elisa", “Aglaia" e "Bárbara". Dessas narrativas, elegemos "Bárbara", conto de $O$ ex-mágico (1947), para uma leitura crítica com foco nos elementos do grotesco. Nesse texto, buscamos refletir sobre a construção grotesca da personagem Bárbara, protagonista da trama, atentando para aspectos que a caracterizam, tais como o exagero ou absurdo, a anormalidade, a ironia e o riso de angústia. 
O conto "Bárbara" é narrado a partir do ponto de vista do marido. Esse narrador personagem mostra como os desejos desmedidos da figura feminina se materializam na construção do seu corpo que aos poucos vai se avantajando em gordura e se tornando anormal, para o padrão estabelecido socialmente. Ao mesmo tempo, a imagem hiperbólica da personagem contrasta com a figura minguada do filho que passa fome e não cresce, ambos se apresentam no relato como protagonistas marcados pela natureza hiperbólica de seus perfis físicos.

\section{O excesso}

Logo nas primeiras linhas, a narrativa dá início à construção da imagem da protagonista, mostrando, por exemplo, que ela possui um desejo, sem limites, de pedir. O narrador nos mostra que à proporção que aumentava o desejo da mulher, seu corpo ia engordando: "Bárbara gostava somente de pedir. Pedia e engordava" (RUBIÃO, 1986, p. 29).

Percebemos que o narrador elege a matéria corporal como objeto da construção do grotesco. O corpo, como bem assim expressou Breton (2020), é um meio de existência. Quando se refere à matéria física do homem, o estudioso defende a ideia de que

\footnotetext{
[e]xistir significa em primeiro lugar mover-se em determinado espaço e tempo, transformar o meio graças à soma de gestos eficazes, escolher e atribuir significado e valor aos inúmeros estímulos do meio graças às atividades perceptivas, comunicar aos outros a palavra, assim como um repertório de gestos e mímicas, um conjunto de rituais corporais implicando a adesão dos outros (BRETON, 2020, p. 8).
}

Frente a isso, é possível entender que o corpo, para além da anatomia, constituído de carne, ossos e outros traços naturais, entendido como unidade material, é também uma espécie de fala e de manifestação dos nossos sentidos, dos nossos valores e das nossas crenças. Além disso, ele é a exteriorização do outro sobre nós, pois as escolhas das nossas expressões e gestos dialogam com o contexto social e histórico em que estamos inseridos, uma vez que, ainda segundo Breton (2020, p. 9), “[...] a expressão corporal é socialmente modulável, mesmo sendo vivida de acordo com o estilo particular do indivíduo".

Ao privilegiar o corpo como objeto para composição da imagem da personagem, o conto remete a sua transformação, mostrando que a metamorfose corporal é um veículo de expressão da figura feminina do composto narrado que, através da matéria física, tenta transpor os limites do mundo. É o que veremos ao longo da nossa leitura.

De início, o narrador personagem preocupa-se em descrever fatos do passado da vida do casal, especialmente de Bárbara. Já nas primeiras linhas tracejadas do conto, percebe-se a 
expressão do exagero descomunal que acontece, sobretudo, pela forma sem limites como a protagonista pede as coisas para o esposo:

\footnotetext{
Por mais absurdo que pareça, encontrava-me sempre disposto a lhe satisfazer os caprichos. Em troca de tão constante dedicação, dela recebi frouxa ternura e pedidos que se renovavam continuamente. Não os retive todos na memória, preocupado em acompanhar o crescimento do seu corpo, se avolumando à medida que se ampliava sua ambição (RUBIÃO, 1986, p. 29).
}

Neste trecho é possível perceber que os desejos desmedidos da personagem aos poucos se refletem na sua forma corporal agigantada, motivo de preocupação do marido. A personagem vai adquirindo uma composição física anormal, segundo às exigências modernas. Esse entendimento é possível de se averiguar quando direcionamos um olhar sobre a história do homem gordo. De acordo com Vigarello (2012), na Idade Média, época em que houve escassez de trigo, o gordo, na figura masculina, era sinônimo de saúde, pois significava que o corpo estava nutrido. Não obstante, ainda segundo o historiador supracitado, para as mulheres da época essa regra ficava à deriva; as mulheres gordas tinham profissões rebaixadas, enquanto as senhoras de classe média mais abastardas se preocupavam bastante com a silhueta, usavam vestidos e espartilhos apertados para mostrar elegância. Até hoje, o corpo magro é mais valorizado entre as mulheres do que o gordo. $\mathrm{O}$ conto, ao expor esse agigantamento da figura feminina, chama atenção para essa exigência moderna de manter o corpo físico em forma. Vejase que enquanto a matéria física da personagem não está em transformação metamórfica, o marido parece não se importar com os seus desejos: "Enquanto me perdurou a natural inconsequência da infância, não sofri com as suas esquisitices. Bárbara era menina franzina e não fazia mal que adquirisse formas mais amplas” (RUBIÃO, 1986, p. 29).

$\mathrm{O}$ agigantamento dos desejos da personagem e de seu corpo cumprem uma importante funcionalidade no relato: o de gerar o sentimento de assombro. A contínua deformidade da mulher que engorda e do filho que definha configura-se como antítese do padrão social e também signo de rebaixamento. Ao mesmo tempo, pode-se dizer que é uma forma da personagem tentar romper barreiras de gênero; na ação, verifica-se que o marido, na busca por seus caprichos, retorna machucado, com isso Bárbara sente-se mais feliz. Nesse conto, não é por acaso que o excesso corporal e o movimento da personagem provocam uma forma de escárnio às regras sociais. Outrossim, pode-se afirmar que a narrativa ironiza o ideal de corpo, pois enquanto no contexto contemporâneo há, entre muitas mulheres, uma preocupação constante em perder peso e manter a forma física, na história ficcional em questão, a preocupação da protagonista consiste em fazer com que seus pedidos sejam atendidos. Não há, 
por parte da figura feminina da narrativa, nenhuma angústia ou apreensão em conter as consequências dos seus desejos, principalmente devido a seus efeitos: a barriga em tamanho descomunal.

Interessante notar a ênfase que a narrativa dá ao ventre. Numa análise mais direta podese verificar dois estágios: o primeiro é quando o ventre cresce porque a personagem está grávida; e o segundo é o momento em que, mesmo depois de dar à luz, sua barriga continua a crescer e a "dilatar-se de forma assustadora" (RUBIÃO, 1986, p. 31). No primeiro caso, vê-se a ideia de renovação por parte do nascimento do filho de Bárbara. Percebe-se, também, a analogia metafórica sugerida nesse ato. $\mathrm{O}$ ventre fecundado é o mundo sem fronteiras, unindo polos positivos e negativos. Aliás, um mundo é o que busca a personagem. Seu corpo, exageradamente obeso, disforme, sugere uma mudança de paradigmas sociais, especialmente nos papeis exercidos pelo homem e pela mulher dentro da família, já que a figura masculina do conto tem como principal função suprir os desejos da esposa; o corpo sugere a busca metafórica da personagem para unir sua matéria à do mundo, numa espécie de supremacia feminina. Por isso, a mulher se agiganta a cada pedido atendido.

Percebemos que o marido experimenta um sentimento de assombro, ao mesmo tempo que a metamorfose vai sucedendo no ventre da esposa. Essa atitude da personagem acentua o diálogo do conto com o campo social, pois mostra que a ascendência feminina caminha numa direção de transcender o ambiente familiar. A imagem corporal é, desse modo, um meio de diálogo com o campo universal social e um meio da protagonista sair metaforicamente do espaço privado. Mais que isso, é uma forma de unir o individual, ou seja, a figura feminina; e o universal, o mundo o qual a personagem tenta alcançar através dos desejos.

A hiperbolização da matéria feminina mostra também que nada está completamente acabado. Como postula Bakhtin (1987, p. 277, itálico no original), “[...] o corpo grotesco é um corpo em movimento. Ele jamais está pronto nem acabado: está sempre em estado de construção, de criação, e ele mesmo constrói outro corpo; além disso, esse corpo absorve o mundo e é absorvido por ele [...]”.

É também plausível pensar, dentro dessa imagem de hiperbolização do corpo feminino que, os desejos em excesso, assim como o corpo metamorfoseado, não culminam com o riso carnavalesco, e sim com o riso moderno de angústia e de desespero. Isso é visivelmente notado pelo comportamento errante do marido diante de tudo que lhe está sendo colocado:

As minhas apreensões voltavam-se agora para seu ventre a dilatar-se de forma assustadora. A tal extremo se dilatou que, apesar da compacta massa de banha que lhe cobria o corpo, ela ficava escondida por trás de colossal barriga. Receoso de que dali 
saísse um gigante, imaginava como seria terrível viver ao lado de uma mulher gordíssima e um filho monstruoso, que poderia ainda herdar da mãe a obsessão de pedir as coisas (RUBIÃO, 1986, p. 31).

O riso angustiante é proveniente, como vimos com Thomson (2019), da ideia de que ele existe dentro do inadmissível. Por isso, cria-se uma sensação que mistura o terrível e o horror. Outra origem do medo pode ser vista através ainda das palavras de Thomson (2019). Segundo ele: "A excitação por algo que não se conforma com os padrões e normas estabelecidos dá lugar ao medo (e a raiva) quando essas normas parecem estar seriamente ameaçadas ou sob ataque" 5 (THOMSON, 2019, n.p, tradução nossa). No conto, essas sensações são possivelmente vistas através da imagem monstruosa de Bárbara:

\begin{abstract}
Numa área extensa, formada por vários lotes, Bárbara acompanhou os menores detalhes da montagem da nave. Eu permanecia sentado no chão, aborrecido e triste. Ora olhava o menino, que talvez nunca chegasse a caminhar com as suas perninhas, ora o corpo de minha mulher que, de tão gordo, vários homens, dando as mãos, uns aos outros, não conseguiriam abraçá-la (RUBIÃO, 1986, p. 31).
\end{abstract}

O modo grotesco de representação da figura feminina do conto "Barbara" instaura uma sensação de absurdo, pois a mulher ultrapassa todos os limites do universo, mostrando seu anseio em possuir um lugar na grande estrutura desse mundo, rompendo com o imaginário do corpo belo. Seu corpo assusta porque revela-se monstruoso e, sabemos, a partir das palavras de Cohen (2000, p. 27) que “[...] o monstrum é, etimologicamente, 'aquele que revela', 'aquele que adverte." ".

A personagem em seu constructo físico degradado revela a persistência desse ser no conto; não somente isso, mostra que diante da liberdade da figura feminina, o marido se sente impotente. Isso é o que nos mostram as palavras do narrador: "O seu corpo era pesado demais para que eu conseguisse arrastá-lo" (RUBIÃO, 1986, p. 33).

\title{
A mescla entre incongruências
}

Uma das características do grotesco apontada por Thomson (2019) é a de que, nessa composição artística, existe a mescla entre realidades, mundo ou objetos incongruentes, ou seja, a junção de elementos opostos. É dessa justaposição que se origina o conflito irresoluto desse motivo literário. Por essa via, no conto, é possível assinalar o confronto entre polos abismais através da personagem Bárbara e do seu único filho. Na representação desses seres ficcionais,

\footnotetext{
${ }^{5}$ No original: "El regocijo por algo que no logra adecuarse a los estándares y normas prefijados da paso el miedo (y a la ira) cuando dichas normas parecen hallarse seriamente amenazadas o bajo ataque."
} 
verificam-se dois polos díspares: de um lado o formato agigantado da mãe gorda e, do outro, a quase invisibilidade do corpo magro do menino, ambos denotando uma subversão da ordem natural das coisas, conforme se verifica no fragmento que segue:

\footnotetext{
Receoso de que dali saísse um gigante, imaginava como seria terrível viver ao lado de uma mulher gordíssima e um filho monstruoso, que poderia ainda herdar da mãe a obsessão de pedir as coisas.

Para meu desapontamento, nasceu um ser raquítico e feio, pesando um quilo (RUBIÃO, 1986, p. 31).
}

Nesse trecho da narrativa, é possível assinalar o medo do marido de que o filho pudesse ter as características gigantescas da mãe. Entretanto, o menino nasce "miúdo e disforme" (RUBIÃO, 1986, p. 31). O contraste entre a gordura da mulher e a sua falta no corpo do filho configura o caráter miscível do grotesco em que se assentam o caricatural e a sátira aos padrões estéticos prestigiados na sociedade. A aludida dualidade acentua o desajuste na topografia familiar, pois ambos habitam o mesmo espaço doméstico. Uma outra questão se impõe nessa relação esfacelada: o rebaixamento dos seres ficcionais. O grotesco nos domínios corpóreos denota uma suposta relação perturbada com o mundo e acentua a degradação das relações binárias do tipo mulher e marido, mãe e filho, adulto e criança, gordo e magro.

Acrescente-se ainda que quando comparada a estatura física do menor com o corpo da mãe, pode-se assinalar o contraste abismal entre esses dois personagens, contraste esse marcado pela desproporção e falta de assimetria física. Embora, desde o princípio possa-se averiguar a rejeição do menino por parte de Bárbara, a tentativa de mescla entre a realidade da personagem feminina de peso exorbitante e a do menino raquítico acontece no plano textual do conto. Essa justaposição de polos abismais é responsável de um lado pela sensação de absurdo por parte do marido, já que a figura feminina, em sua abundância corporal e em sua rejeição ao menino, faz com que o mesmo se torne um eterno magricela; do outro lado, percebe-se, mais uma, vez o riso de angústia, pois a situação é irônica e grotesca, uma vez que não se admite o apequenamento e a desnutrição do filho ante a mãe esbanjando gordura e leite: "A insensibilidade da mãe, indiferente ao pranto e à fome do menino, obrigou-me a criá-lo no colo. Enquanto ele chorava por alimento, ela se negava a entregar-lhe os seios volumosos e cheios de leite" (RUBIÃO, 1986, p. 31).

Desse modo, desfruta-se, nesse conto de Murilo Rubião, de uma imagem que parece ultrapassar todos os limites do mundo coeso, já que nos é apresentada uma personagem com desejos incontroláveis e alheia às necessidades do filho. Por isso, vislumbra-se no relato a 
materialização de um sentimento de horror e de angústia por parte do marido que vive na sombra da esposa, buscando sinais de migalhas de amor e de gratidão de Bárbara:

Feliz e saltitante, lembrando uma colegial, Bárbara passava as horas passeando sobre o grosso tronco. Nele também desenhava figuras, escrevia nomes. Encontrei o meu debaixo de um coração, o que muito me comoveu. Este foi, no entanto, o único gesto de carinho que dela recebi (RUBIÃO, 1986, p. 31-32).

Em outro momento do conto, esboça-se novamente o contraste entre esses dois personagens. Desta vez, percebe-se a ênfase do narrador em mostrar que o menino, devido ao seu tamanho físico e a sua desnutrição tem que ser carregado nos braços: "O menino tinha que ser carregado nos braços, pois anos após o seu nascimento continuava do mesmo tamanho, sem crescer uma polegada" (RUBIÃO, 1986, p. 32). A secura ou definhamento configura-se como metáfora da ausência de vitalidade do menino em oposição à imagem agigantada da grávida, emblema de vida no ventre.

Através da passagem acima citada, é possível notar que as ações acontecem no conto como se fossem um eterno ciclo. Para o pequeno, os anos se repetem sem nenhuma transformação; a criança em permanente condição de inércia, enquanto a mãe, seguindo o ritmo obsessivo de pedir, avoluma-se desmesuradamente na estranheza de seu corpo caricaturizado. A ideia de ciclo pode ser assinalada através do advérbio de tempo SEMPRE, que aparece na seguinte sentença: "Jamais compreenderia o meu amor e engordaria sempre” (RUBIÃO, 1986, p. 32).

Faz-se igualmente necessário levar em consideração a seguinte ideia: se há, por parte da personagem feminina, uma suposta tentativa de transcender os limites do universo, como visto anteriormente, é possível dizer que essa tentativa se esboça na matéria narrativa através do contraponto existente entre os formatos corporais da mãe e do filho. Bárbara, conforme já vimos em trecho citado, não se pode abarcar com os braços; o menino, por sua vez, não se sustenta e tem que ser carregado. Nesse sentido, o escritor expõe esse conflito, uma mescla entre realidades díspares, contrastantes, incompatíveis e inaceitáveis como um retrato figurativo da desordenada realidade das personagens.

\section{Dos desejos}

A tragicidade da vida que sustenta a teorização do grotesco, formulada por Kayser (2013), permite-nos confrontar, na leitura do conto, a intencionalidade satírica que alicerça o drama das personagens e o imaginário do corpo. Em "Bárbara”, o grotesco também se configura pelos desejos incomuns da personagem e pelos efeitos desses desejos em seu corpo. A mania 
de pedir, como assim se refere o narrador ao hábito estranho da personagem, tem como origem, em sua maioria, os elementos cósmicos: ora é o oceano, ora são os astros celestes. A personagem pede coisas grandes e vai corporalmente acompanhando a imensidão física dos seus pedidos.

Por medo de que o filho pudesse morrer ou acontecer uma calamidade maior, o marido implora que sua mulher peça qualquer coisa. Então Bárbara "pediu o oceano” (RUBIÃO, 1986, p. 30), e o marido, sem fazer nenhuma objeção, embarca no mesmo dia a fim de conseguir realizar o pedido da esposa. Por temor de sua esposa atingir o tamanho do oceano, ele a presenteia com uma garrafa contendo água. Desse desejo da figura feminina, depreende-se uma discussão em torno do conceito de realidade e de espaço. O mar possui uma extensão sem limites. Com isso, podemos dizer que o conto sugere essa busca de transcendência da personagem que, através dos símbolos contidos no objeto desejado, enuncia essa ausência de barreiras no universo; enuncia espaços sem limites. Supostamente, Bárbara anseia assumir um lugar para além dos limites do universo, deseja alcançar uma dimensão macro do mundo. Contudo, a garrafa d'água que o marido lhe dá em substituição ao oceano aponta a impossibilidade de transcendência igualmente a do oceano: "Dormia com a garrafinha entre os braços e, quando acordada, colocava-a contra a luz, provava um pouco de água" (RUBIÃO, 1986, p. 30).

A imagem que se impõe ao leitor a partir da hiperbolização do desejo e da ironia no tratamento do grotesco se torna mais evidente no jogo desintegrador das personagens mãe e filho - que se avoluma ou definha, respectivamente - caminhando para o bizarro: "Entrementes engordava" (RUBIÃO, 1986, p. 30). Poder-se-ia pensar que a mulher, à medida que ingere a água do mar, imergisse para dentro de si um pouco dessa infinitude, mesmo em um nível bem menor do que o do oceano. Por isso, ela nunca se sacia e, assim, continua a pedir.

Do ponto de vista do narrador, a figura feminina, quando cansada do mar, pede um baobá que se encontrava em um terreno ao lado de onde moravam. A princípio, o marido arranca um galho da planta, mas isso não satisfaz a esposa. Então ele se vê na obrigação de comprar a propriedade, já que o vizinho se recusa a vender somente a árvore. A personagem fica feliz com o presente do marido e passa horas passeando em torno do tronco grosso. Doravante, continuava a engordar.

Os recorrentes pedidos da protagonista assumem a função de estagnação do ser, pois não há a saciedade. O inconformismo perturbador da mulher é temível, do ponto de vista do marido. O exagero de cada desejo emblematiza uma escala na distorção anatômica e na construção monstruosa da protagonista, daí a transgressão da ordem. 
No relato, a tônica dada aos pedidos da figura feminina, como um elemento do céu, por exemplo, parece remontar a um caráter psicológico: ela não pede a lua como temia o marido, mas uma estrela bem pequena ao lado do astro. Essa rejeição da lua em relação à estrela sugere uma suposta ambição. A lua não tem luz própria, depende da luz da maior estrela do sistema solar para poder ter visibilidade, ou seja, do sol. Nesse sentido, desejar um objeto celeste com luz própria configura-se como metáfora de um realismo brutal ligado às relações de gênero: o desejo de ter sua própria luz e não depender da iluminação de uma figura masculina. Útil destacar o sentido simbólico desse astro desejado por Bárbara: "Seu caráter celeste faz com que eles $^{6}$ sejam também símbolos do espírito e, particularmente, do conflito entre as forças espirituais (ou de luz) e as forças materiais (ou das trevas). As estrelas traspassam a obscuridade" (CHEVALIER; GHEERBRANT, 2009, p. 404).

Assim sendo, a presença do astro luminoso no conto sugere o confronto entre o mundo material e o espiritual, assim como o enfrentamento entre polos abismais, no caso a luz e a escuridão. A personagem está em busca de transcender. Isso é perceptível através dos seus pedidos, em sua maioria, de elementos cósmicos, portanto, fora da ordem lógica do mundo, por isso a sensação de assombro tão sugestiva no conto.

A partir da seleção de objetos desejados por Bárbara, é possível aferir que o conto de Murilo Rubião é bastante audaz em sua arquitetura ficcional. A narrativa não trata da materialidade das coisas em si. Vai além, mostrando que o sentido maior da vida está em almejar o que é de mais essencial à existência humana. Pode parecer descomunal, desordenada ou ilógica a situação representada, mas é uma forma possível de satirizar a vida, questionando, por exemplo, o valor das coisas. A ação da mulher causa espanto ao marido e, porque não dizermos, ao leitor, uma vez que se constrói no que poderíamos considerar como a mais extrema e "desordenada" realidade. O processo metamórfico da personagem, munida de tantos anseios considerados estranhos, aponta para o desprendimento de uma realidade e o alcance de outra.

\section{Conclusão}

"Bárbara" é um conto que nos permitiu uma reflexão crítica, tendo como pressuposto o motivo do grotesco. Na narrativa, é possível assinalar diversas metáforas que culminam para uma imagem corporal monstruosa da personagem. Três fatores chamam atenção na configuração do grotesco, são eles: primeiro, a convulsão e, em decorrência disso, o corpo

\footnotetext{
${ }^{6}$ Os astros (estrelas).
} 
avantajado da mulher; segundo, o encolhimento do filho; e, por fim, os pedidos bizarros, desintegradores e descomunais da protagonista, causando estranheza.

O grotesco concorre assim para causar a sensação de espanto e mesclar o possível e impossível. Com isso, pode-se afirmar que o conto muriliano induz a uma reflexão sobre o lugar social da mulher e o seu desejo por transcendência.

Em nossa leitura também foi possível notar que, no plano textual, há uma mescla entre realidades abismais. Esta justaposição instaura a sensação de riso de horror, uma vez que a realidade apresentada é inadmissível. Com isso, o conto satiriza a vida e mostra que o mundo absurdo do qual tentamos fugir está mais próximo de nós do que imaginamos.

De certa forma há em todo o conjunto dessa narrativa de Murilo Rubião um grotesco que se constrói na imagem de exagero que se agrava pelos estranhos pedidos de Bárbara. A personagem pede coisas do mar, da terra e do céu - presentes descomunais. Dessa forma, depreende-se a vontade da figura feminina de unir seu corpo ao universo, pois à proporção que os pedidos aumentam, a mulher se agiganta fisicamente. Assim, na configuração do corpo grotesco e também nos desejos expressos da personagem foi possível perceber a ridicularização dos atos e, assim, o caráter risível do conto.

\section{Referências}

BAKHTIN, Mikhail Mikhailovich. A cultura popular na Idade Média e no Renascimento: o contexto de François Rabelais. Tradução de Yara Frateschi Vieira. São Paulo: Editora da Universidade de Brasília, 1987.

BRETON, David Le. A sociologia do corpo. 6. ed. Petrópolis-RJ: Editora Vozes, 2020. CHEVALIER, Jean; GHEERBRANT, Alain. Dicionários de símbolos: mitos, costumes, gestos, figuras, formas, figuras, cores, números. Tradução de Vera da Costa e Silva, et. al. 24. ed. Rio de Janeiro: José Olympio, 2009.

COHEN, Jeffrey Jerome. A cultura dos monstros: sete teses. JAMES, Donald. et al (Orgs). Pedagogia dos monstros: os prazeres e os perigos da confusão de fronteiras. Belo Horizonte: Autêntica, 2000.

CONNELLY, Frances S. Lo grotesco en el arte y la cultura occidentales: La imagen en juego. Madrid: Antonio Machado Libros, 2015.

HUGO, Victor. Do grotesco e do sublime: tradução do prefácio de Cromwell. Tradução e notas de Célia Berrettini. 3. ed. São Paulo: Perspectiva, 2010.

KAYSER, Wolfgang Johannes. O grotesco: configuração na pintura e na literatura. Tradução de J. Guinsburg. São Paulo: Perspectiva, 2013. 
RUBIÃO, Murilo. Bárbara. In: RUBIÃO, Murilo. O pirotécnico Zacarias. 11. ed. São Paulo: Editora Ática, 1986.

RUSSO, Mary. O grotesco feminino: risco, excesso e modernidade. Rio de Janeiro: Rocco, 2000.

THOMSON, Philip. Lo grotesco. Apresentação e tradução de Rodolfo Palma Rojo. México: Fomento Editorial, 2019.

VIGARELLO, Georges. As metamorfoses do gordo: história da obesidade no Ocidente: da Idade Média ao século XX. Tradução de Marcus Penchel. Petrópolis/RJ: Vozes, 2012.

Recebido em: 25/02/2021 Aceito para publicação em: 04/05/2021 